\title{
Open landfill site and threat to the proximity resident's: Addressing perceived consequences of unscientific solid waste dumping using GIS techniques
}

\section{Subham Roy ( $\nabla$ rs_subhamroy@nbu.ac.in )}

University of North Bengal Faculty of Science https://orcid.org/0000-0003-1685-3860

\section{Arghadeep Bose}

University of North Bengal Faculty of Science

\section{Debanjan Basak}

University of North Bengal Faculty of Science Indrajit Roy Chowdhury

University of North Bengal Faculty of Science

\section{Research Article}

Keywords: Landfill site, Solid waste, Landfill pollution, Perception, GIS, Environmental risk

Posted Date: January 7th, 2022

DOI: https://doi.org/10.21203/rs.3.rs-1231009/v1

License: (c) (1) This work is licensed under a Creative Commons Attribution 4.0 International License.

Read Full License 


\section{Abstract}

Municipal solid waste (MSW) disposal is a rapidly expanding sector that caters to the rising demand for disposal facilities; as a result, MSW treatment is becoming a significant challenge in concern to environmental and public health. The by-products of solid waste dumped in landfills have negative consequences on the environment and people living near disposal sites. This research aimed to assess whether the disposal of garbage in landfills affected the people who live near them. Consequently, residents living near MSW disposal facilities are exposed to various risks. A systematic questionnaire was devised and disseminated in this research to examine the adjacent people's concerns and attitudes around the landfill of the rapidly expanding Siliguri city of West Bengal. It was accomplished by assessing the opinions of persons living within the $1000 \mathrm{~m}$ of the landfill site and how it impacts their life. The novelty of the research includes geographical analysis of physical impressions, including odour nuisance, breathing problems, impacts of flies and mosquitoes, water contamination, issues due to illegal burning, and health-related problems, which was conducted using geographic information system methodologies. Besides, the Landfill satisfaction index (LSI) tool was used to assess the perception of the people residing near the landfill. Also, to statistically validate the perception of the people related to the impact of landfills on their life, gamma coefficient ( $y$ ) test of Goodman-Kruskal was applied. The findings reveal that the majority of the respondent within $600 \mathrm{~m}$ are more susceptible to various risks due to unscientific landfill. Subsequently, a large portion of the responding sample was aware of the detrimental effects of landfills on the health and environment, therefore, individuals living near the dump yard preferred to live farther away. The findings also reveal that geographical proximity has a clear relationship between respondent perception and distance to the landfill. The study concludes with a discussion on how the research results may be beneficial for designing landfill sites and can be utilized by urban planners, environmentalists, and engineers.

\section{Introduction}

Urbanization, lifestyle changes, and growing population are primarily responsible for the increasing amount and diversity of solid waste generated in developing nations (Alam and Ahmade 2013). However, the existing Municipal Solid Waste (MSW) management procedures, notably collection, processing, and disposal, are deemed inefficient. Consequently, environmental and health issues are becoming more prevalent in these nations (Srivastava et al. 2015). It has become increasingly necessary to find new ways to dispose of municipal solid waste (MSW) because of the lack of landfill space (Blumberg and Gottlieb 1989; Purcell and Magette 2010). Even though landfills efficiently remove vast amounts of MSW, but the public objection to these facilities seems to be rising (Marshall and Farahbakhsh 2013) as communities have been forced to dump solid wastes in open fields in an unscientific manner, roadsides as well as river banks and perform open burning, causing colossal damage to air and water due to absence of well-established MSW management systems (Ejaz et al. 2010; Tyagi et al. 2014).

For public health and environmental-related concerns, open dumping is a serious issue in urban areas (Sankoh et al. 2013; Boadi and Kuitunen 2005). In most developing nations, including India, open 
dumping is the most typical technique of managing urban garbage that is neither scientific nor planned (Henry et al. 2006; Tyagi et al. 2014). Toxic gas emissions from open burning may be caused by uncontrolled and poorly managed landfills of trashes (Boadi and Kuitunen 2005; Srivastava et al. 2015). Decomposing organic waste in landfills releases greenhouse gases and pollutes the surrounding soil and water bodies (Lim et al. 2016). MSW clogs the drains in urban areas, resulting in stagnant water suitable for breeding insects and overflows during the rainy season (Ejaz et al. 2010).

Subsequently, Various diseases have been linked to the illegal disposal of municipal solid waste (MSW) (Reinhart 1993; Sharholy et al. 2008). People who live in a garbage-strewn neighborhood are more likely to have malaria, diarrhea, and respiratory diseases (Zohoori and Ghani 2017). Individuals may also be exposed to a variety of diseases and other toxins if they use contaminated MSW water for drinking, bathing, and irrigation purposes (Alam and Ahmade 2013). People who live near garbage disposal facilities are more likely to suffer from respiratory symptoms, skin, nose, and eye irritation, gastrointestinal issues, fatigue, headaches, and psychological issues, as well as allergies (Gouveia and Prado 2010; Abul 2010).

Municipal trash often includes significant quantities of various organic and inorganic components that are readily decomposed by a variety of microbes of different species (Semrau 2011; Alam and Ahmade 2013). Byproducts of municipal garbage, such as volatile organic compounds, ammonia, organic sulfur compounds as well as hydrogen sulfide, which are produced under anaerobic circumstances, have a significant impact on the health of the community's inhabitants (Bobeck 2010; Mataloni et al. 2016). As a result of uncontrolled municipal solid waste incineration, a large number of pollutant particles, such as Particulate Matter (PM), SO2, CO2, $\mathrm{CO}$, furans, and dioxins, are released into the environment. Exposure to these pollutants may have a significant negative impact on the physical as well as mental health of residents in the vicinity (Roberts and Chen 2006; Silverman and Ito 2010).

Children, the elderly, and those with chronic diseases like asthma or pre-existing cardiovascular disease tend to be particularly vulnerable to these effects (Zanobett 2000; Rushton 2003). Chronic exposure to low concentrations of these toxic pollutants emitted from MSW has been connected with chronic health impacts such as impaired lung function, higher rates of bronchitis, shorter life span, heightened rates of respiratory complaints, and lung cancer (He et al. 2015). Ambient air pollution due to landfill is connected with unfavorable birth outcomes, such as premature birth, low birth weight, births at a short gestational age, as well as premature deaths (Porta et al. 2009; Kumari et al. 2019).

The public's reaction to environmental exposure is heavily influenced by risk perception (Slovic 2000). The findings on people's perceptions of the effect of poor MSW management methods are varied. According to some research, the public believes that insufficient solid waste management contributes to illness causation and pollution, while others claim that the public does not correlate municipal garbage with negative health impacts (Addo et al. 2015; Babs-Shomoye and Kabir 2016).

There is a lack of efficiency in India's MSW management system (Asnani and Zurbrugg 2007; Ojha 2011). Open dumping, open burning, and unscientific sanitary landfills have become the norm across large 
swaths of the nation (Joshi and Ahmed 2016; De and Debnath 2016). Located in the state of West Bengal, Siliguri is not an exception. Don Bosco Colony, which includes Don Bosco School and Silesian College, has a dumping area where all of the city's solid garbage is collected and deposited without any sorting. In order to reduce trash volume, it is fairly common to light it on fire (Vaverková 2019). The pollution of water, land, and air in the vicinity of the Siliguri dumping ground has been caused by uncontrolled open dumping and open incineration (Roy and Mandal, 2019). However, little attempt has been made to investigate the people's comprehension, experience, and attitude to the open dumpsite. Therefore, the present study adopted residents' perception due to unscientific landfill as a critical way to understand the effects of garbage exposure and design effective treatments.

The findings of this study shed light on the general public's perspective of environmental concerns and the individuals living near a Siliguri dumping area. Using GIS, researchers were able to establish the allowable distance between homes and dumping grounds and the relationship between distance and dumping site issues (Balram and Dragićević 2005; Higgs and Langford 2009). In order to improve the environmental quality, life of the local inhabitants as well as the efficiency of facility evaluation and design, this information would be beneficial to planners and governments alike. Furthermore, the study's results might serve as a call to action for the town's governing authority to include citizens living near the town's open dumpsite in its efforts to provide a better quality of life for the whole community (Rahardyan et al. 2004). A better knowledge of the viewpoints of the inhabitants near the open dumpsite is envisaged to motivate the town and municipality to actively participate in the development, implementation, and enforcement of a successful MSW management system for Siliguri.

\section{Location of the study area}

Siliguri is one of the fast-growing cities in West Bengal, India, which is situated in a small corridor that links Nepal in the northwest, Bangladesh in the south, and Bhutan in the north, making it the "gateway to north-eastern India" (District Census Handbook, 2011; Roy and Singha 2020). This favorable location is responsible for the city's tremendous economic and demographic expansion. According to the 2011 census, within 41.9 sq.km, Siliguri had a population of 5.13 lakhs, with a booming density of 11,274 people per sq. $\mathrm{km}$ distributed over 47 wards; however, the city has withstood an almost five-fold increase in its population density since 1931 (CDP report Siliguri, 2015; Roy et al. 2021). Therefore, such a tremendous increase in population result in excessive generation of solid waste per day. According to the study of Roy and Mandal (2019), the daily waste generation of the Siliguri city comprises 350-400 tons per day which rises to 500-600 tons/day during the festive seasons. As a result of such excessive amount of waste generation, the local administrative bodies failed to manage it appropriately, and as a result, unscientific landfill was taken place.

Insert Fig. 1 
The Siliguri landfill site is located in the north-eastern corner of the city, namely at Dabgram 1, between the Don Bosco School and the Eastern Bye-Pass road. It is situated in between ward number 41 and 42 (Fig. 1). The area covered by the Siliguri landfill is about 28 acres, but due to excessive population burden and encroachment, the actual size remains 22 acres (8.9 ha) (CDP report Siliguri, 2015). Residents living near the Siliguri landfill are concerned about contamination of ground and surface water and the nuisance consequences of dust, smell, and visual intrusion. The daily garbage that arrived at the landfill site accumulated, and the adjoining area quickly became an open waste dumping area. As a result, it impacts people's everyday lives, resulting in dissatisfaction and opposition (SL. Fig 1).

\section{Materials And Methodology}

The Siliguri dumping yard is situated less than 100 meters from residential areas. As a result, the purpose of this study was to learn about residents' impressions of the landfill's influence on their health and way of life. In order to begin, a reconnaissance study was conducted surrounding the landfill site to determine the dwellings and other functional institutions in the vicinity. The present study involves completing various activities, including literature research and field surveys, as well as GIS-based procedures like gridding-based approach, result visualization, and quantitative techniques (Fig. 2). The present study has been applied around $1000 \mathrm{~m}$ of landfill area of Siliguri Municipality.

Insert Fig. 2

\section{Participants and Sampling Technique}

Before the research, a preliminary survey was undertaken to determine the most affected residents due to unscientific landfills. In order to examine the activities from the dumping site, an initial visit was performed through a perimeter walk nearby the landfill area. It is done to provide the researcher with firsthand knowledge of the facility's operation and gain a situational viewpoint from community members. During the tour, the researcher engaged the inhabitants in an unstructured interview to establish the nature of the landfill's impact on the neighborhood. However, according to the previous studies, people residing within the proximity of $500 \mathrm{~m}-2 \mathrm{~km}$ from the landfill sites are severely affected (De and Debnath 2016; Ganesan 2017; Urme et al. 2021; Singh et al. 2021). As a result, two techniques, namely purposive and criteria sampling procedures, were used to collect the data for the present study. Purposive sampling was chosen because, in this approach, a certain group of people, events, or activities are purposely chosen to offer knowledge that is not available from other sources since only a small group of people can supply the most helpful information (Moser \& Korstjensc 2018). Therefore, Purposive sampling can meet the research's goal because the present study emphasis primarily on the 'cases of exposed population'to the landfill (Singh et al. 2021). 
Subsequently, the criterion sampling technique was another consideration for the present study, which includes the cases that only meet the requirements. However, according to Patton (2002), Criterion sampling entails choosing cases that fulfill some predetermined criterion of relevance. Therefore, for the present study, only those participants are selected those who meet the following criteria (i) Exposed household population to the landfill sites within $1000 \mathrm{~m}(1 \mathrm{~km})$ radius concerning municipality jurisdiction (which is divided at an interval of $200 \mathrm{~m}$ buffer), (ii) at least one year of residence near the landfill sites (Ganesan 2017; Njoku et al. 2019; Etea et al. 2021; Singh et al. 2021). However, a total of 400 questionnaires were distributed among the residents near the landfill sites (within $1 \mathrm{~km}$ ), and among them, 384 questionnaires were collected with a $96 \%$ response rate.

\section{Gridding based GIS approach}

According to the study of Che et al. (2013), the gridding-based approach using GIS techniques can be utilized to assess the impact of a landfill site on the residents who live within the proximity. Thus the present study adopted an integrated GIS-based gridding approach with questionnaire-based perception surveys to conduct a more efficient and scientific investigation of the study region from a holistic viewpoint. However, for the present study, each cell size of 150 meters was considered, and there are 115 cells matrix in total, including ten cells with vacant sites and 105 cells with inhabited locations. In the next step, it is identified that one major college and school were situated within less than $500 \mathrm{~m}$ from the landfill sites, and thus perception about the impact of unscientific dumping was also considered from both institutions in the present study (Fig. 1). However, these 115 inhabited cells were finally categorized into five divisions at an interval of $200 \mathrm{~m}$ buffer to evaluate the perceived consequences.

\section{Formulating Questionnaire design and data collection strategy}

At first pilot survey and group discussion were conducted to identify the issues related to a locality near the landfill sites in order to design a questionnaire that appropriately reflects and describes the difficulties faced by local inhabitants (Srangsriwong 2019). Subsequently, the final interviews were done using a semi-structured questionnaire (includes both open and close-ended questions), which allowed respondents to express a wide range of opinions on how the dumpsite has impacted their lives. Besides, quantitative techniques like site observation, focus group discussion, and note on perceptions were also adopted to understand better their real-life scenarios and adjustments near the landfill sites (De and Debnath 2016; Weldeyohanis 2020; Urme et al. 2021; Etea et al. 2021). However, all these data were collected with the help of some enumerators after proper instruction and preparation. The final questionnaires are easy yet comprehensive, which help to gather information on issues related to the public perceptions of the research area. The questionnaire was divided into two sections: sociodemographic information like age, sex, gender, education, occupation, and duration of residence included in the first section. While the second section includes the risk perceptions of the people residing near the landfill sites, which consequences their health and environment (at an interval of $200 \mathrm{~m}$ buffer which covers up to $1 \mathrm{~km}$ ). This second section contains five-point Likert scale questions, and each respondent 
was given a list of six landfill impacts questions, e.g., Due to nearby landfills, how do you suffer from odour annoyance? Moreover, the responses vary from a 'very serious problem' (indicating 5) to a 'not at all problem' (indicating 1). Besides, one question was included at the top of the questionnaire, which includes the coordinates of the respondent residence, which help to determine their distance from landfill sites and also necessary for the gridding based approach using GIS technology which helps to visualize the impact of landfill over the people (Che et al. 2013).

\section{Landfill satisfaction index (LSI)}

Landfill satisfaction index (LSI) is an aggregated tally of each answer received from the participants related to the perceived impact of landfill sites. Furuseth and Johnson (1988) first developed the LSI tool in their research to analyze the perceptions of the peoples residing within $4800 \mathrm{~m}$ of the Harrisburg landfill site (at an interval of $800 \mathrm{~m}$ ). Subsequently, the study of Okeke and Armour (2000) applied the LSI tool to evaluate the respondent attitude towards nearby landfill sites within the proximity of $1600 \mathrm{~m}$ of Halton city. Therefore, for the present study, LSI was adopted to understand the perceptions of people residing in proximity to $1000 \mathrm{~m}$ in the Siliguri landfill site. For the construction of the LSI tool, scores for every six questions related to the landfill impacts were summed. Since the 5-point Likert scale questionnaire was used, the LSI for Siliguri ranged from 6 to 30, indicating 6 with a very low problem ( 1 score for all response) and 30 reflecting very serious problems (5 score for all response).

\section{Results And Discussion}

\section{Demographic characteristics}

The socio-economic condition of respondents living near the municipal dumping area in Siliguri Municipal Corporation (SMC) is shown in SI. Table 1. For the perception survey, a total of 384 people were considered, including 224 men and 160 women, with 66.1 percent of the sample population being married, indicating that the male-to-female ratio was acceptable and that the bulk of the sample population is middle-aged and older (58.6 percent older than 30 years). Besides, Students (18.5 percent) and housewives (10.9 percent) were also included in the sample survey and the government or private work or business, which accounted for 70.6 percent of the respondent's occupation. The sample population considered had a literacy rate of $97.9 \%$. (Minimum of primary education). According to the sample, $31 \%$ of the respondent stay for $10-15$ years within the proximity of landfill, followed by $22.9 \%$ stay for $15-20$ years, $21.1 \% 5-10$ years, $13.5 \%$ for $1-5$ years, and only $10.7 \%$ of respondent stay for more than 20 years. However, Figure 3 reveals about the perception of the respondent concerning landfill site

\section{Insert Fig. 3}

\section{Spatial analysis of perceived impacts due to open landfill}


Pungent odour is one of the major problems faced by any people residing near the open landfill, causing discomfort and annoyance (Aatamila et al. 2010; De and Debnath 2016). Some landfill gas (LFG) components, like hydrogen sulfide, methane are essential contributors to pungent smell originating from a dumpsite (Vrijheid 2000) which is mainly due to poor landfill management, such as improper compression of garbage dumped in the landfill and a lack of collection and use of LFG emissions (Njoku et al. 2020). Similarly, in the case of Siliguri landfill, an unpleasant odour emanating from landfills is a significant issue faced by the nearby residents and dump employees. The odour released by the waste has made people's life difficult. It pollutes the air and has a detrimental impact on individuals walking or driving along the roads adjacent to the landfill sites. According to the study, $28.6 \%$ of the respondents report severe problems due to pungent odour followed by $25 \%$ high, $19.5 \%$ moderate, $16.1 \%$ minor, and $10.7 \%$ not at all problem, respectively (Table 1). The respondent further reported that the frequency of noxious smell occurrence was higher in summer compared to other seasons. Besides, Siliguri experience extreme temperature, high humidity with low pressure between the month of June to August (Roy et al. 2021), and during these months, the condition near the dumping ground was unbearable, according to the study. This study found a strong link between odour discomfort and distance from the landfill, with the majority of the respondents residing within $600 \mathrm{~m}$ (24 cells) reporting very high odour discomfort (Fig. 4). However, the aggravation lessened as the distance from the landfill increased. Subsequently, the respondent who resides within $800 \mathrm{~m}-1000 \mathrm{~m}$ reported very low odour annoyance.

\section{Insert Table 1}

Another finding suggests that the presence of odours nuisance was linked to the direction of the wind. The Figure 4 reveals that the odour was concentrated in the north and north-eastern part of the landfill site, which might be explained by the wind direction, and mostly blow in the northern direction throughout the year, especially in the summer. However, some cells in the southwest and southeast part contradict the pattern, possibly due to the barren land ( 5 uninhabited cells) in the southern part of the landfill site; as a result, the odour is not restricted within the vicinity and spreads throughout the southern part.

\section{Insert Fig. 4}

On the other hand, a very serious problem due to water contamination is mainly reported by the people within proximity of $600 \mathrm{~m}$ (Fig. 5), besides some of the grids ( 10 cells) within $600 \mathrm{~m}$ having serious problems. However, $22.1 \%$ of the respondents report a serious water pollution problem distributed mainly in the north-western and southern parts of the landfill site. According to the perception of the respondent's water contamination is a seasonal phenomenon that mainly increases in the monsoon period (JulySeptember) because rainfall has a significant impact on leachates formation, which percolates through the soil, causing water contamination (Vaverková 2019). According to studies, landfills contaminate 
groundwater because leachate percolates into groundwater through cracks in membranes and contaminates it due to high bacterial content (Okeke 2000; Maqbool et al. 2011; Edokpayi et al. 2018). Although no laboratory investigation of groundwater in the region was performed for this study, however according to the perception of respondents, those who reside near the 400-600m of landfill site experience salty and bitter taste of water due to leaching. According to the previous studies, some of the major toxic compounds that change water taste near landfills include chloride, lead, and mercury (Akinbile and Yusoff 2011; Ololade et al. 2019; ICCDI Africa 2020). Subsequently, those who reside within $800-1000 \mathrm{~m}$ of the Siliguri landfill report almost no problem.

\section{Insert Fig. 5}

Breathing issues are another common problem people face near landfills; about $24 \%$ of the respondents face severe breathing issues, followed by $24.2 \%$ of serious issues. According to the Fig 6 respondent, those who reside in the western part of the dumping ground facing various issues related to breathing problems. According to previous studies, residents who live near an open dumping site are more likely to get respiratory ailments, supported by the present study (Sankoh et al. 2013; Palmiotto et al. 2014; Njoku et al. 2019). Bioaerosols and biological substances emitted from garbage sites can induce respiratory disorders like asthma, chronic obstructive pulmonary disease (COPD), and breathing disorder (Heldal et al. 2003; Kret et al. 2018). Aside from biological agents and volatile organic compounds generated by landfills, emissions from automobiles, trucks, and bulldozers utilized in the landfill site can also contribute to excessive emissions (Vimercati et al. 2016). Such emissions have harmed human health (Njoku et al. 2019). Therefore, it is not unexpected that respondents who lived up to $600-800 \mathrm{~m}$ from the dumpsite of Siliguri also reported moderate to minor breathing issues (Fig. 6).

\section{Insert Fig. 6}

Besides, Landfill fire is a widespread and frequent phenomenon in Siliguri dumping sites that mainly occur during dry seasons of summer and winter (Siliguri Times 2021) (SL. Fig $2 \& 3$ ). According to the findings, residents within 400-600m are the most affected in terms of burning issues (Fig. 7). On the other hand, people away from the landfill (600m away) report minor and not at all problems. Landfill fires may cause serious environmental damage by releasing poisons into the atmosphere, land, and water. The type of garbage, the location of the dump, and the sort of fire all influence risk factors (Toro et al. 2018). These flames often occur at low temperatures and in anoxic environments. In such settings, hydrocarbons, chlorinated materials, and pesticides create a range of hazardous gases, including dioxins/furans (Escobar-Arnanz et al. 2018), respirable particles (PM), and heavy metals (HM) (Rovira et al. 2018), as well as other damaging chemicals (Nadal et al. 2016). Smoke from the landfill fire might contain poisonous gases, including $\mathrm{CO}, \mathrm{H} 2 \mathrm{~S}$, and $\mathrm{CH} 4$, as well as carcinogenic chemicals like dioxins. 


\section{Insert Fig. 7}

According to the respondent, the waste dump catches fire throughout the summer and winter seasons, either due to spontaneous combustion as a result of chemical reactions and methane generation or due to people's negligence, or due to the act of miscreants. Residents faced severe trouble in the surrounding area due to smoke and harmful gases resulting from waste burning in the landfill causes foul odour and also cause congestion in respiratory tracts.

Open landfill areas are susceptible to the incubation and multiplication of flies, mosquitoes, rodents, and cockroaches; as a result, it becomes a source of pollution (Singh et al. 2021); breeding of such insects are common around the landfill, which consequences in spreading of vector-borne diseases causing threat to the nearby residents (Urme et al. 2021). Besides, the problems due to flies, mosquitoes, and rodents have been studied for many years (Dhillon \& Challet 1985; Howard 2001; Lole 2005), but there has been a scarcity of work related to the perceived impact of such insects using GIS technology. However, the present study reveals that the entire study area (within $1000 \mathrm{~m}$ of landfill) is highly affected by the menace of flies, mosquitoes, and rodents (Fig. 8). About $36.2 \%$ of the respondent who resides within the $800 \mathrm{~m}$ distance (except few cells) face a very serious problem, followed by $39.1 \%$ of respondents who are susceptible to a serious threat of such insects. Except for a few grids (six cells) in the extreme northern and southern parts, the entire study area faces the issues of flies, mosquitoes, and rodents. According to the respondents, the impact of flies and mosquitoes became very high, mainly during the summer and monsoon seasons; as a result, some people nearby the landfill always shut their doors and windows daily to keep insects rodents out. Previous studies also support that during summer and monsoon, their adaptive capacity and incubation ability increase (Howard 2001; The conversion 2018; Ahmed et al. 2019). Therefore, landfills act as a breeding place for such insects, especially during the monsoon season, and hence diseases like dengue fever, malaria, and diarrhea are prevalent within the proximity area.

\section{Insert Fig. 8}

According to the previous study, residents who live closer to landfill sites are more likely to suffer from medical issues such as asthma, infections, diarrhea, stomach ache, recurrent flu, cholera, malaria, cough, skin irritation, cholera, diarrhea, and TB than those who live further away (Vrijheid 2000; Bridges et al. 2000; Brender 2011; Njoku et al. 2019). Similarly, the present study reveals that those who reside mainly within the 400-600m report severe health-related problems (Fig. 9). According to the study, the major problems reported by the people near the Siliguri landfill are stomach-related problems, skin rashes, wounds, frequent fever, and diarrhea. Besides, some of the respondents also report respiratory problems like asthma and cough, mainly due to the bioaerosol exposure linked to a variety of respiratory disorders, 
including inflammation of the airways (Heldal et al. 2003). According to the study's findings, local inhabitants are aware of the many ailments that may arise from the exposure of particular hazardous waste and living near a dumping ground as $24.2 \%$ of respondents report very serious health issues followed by $17.4 \%$ serious problems. However, in the present study, whenever respondents report two or more than two ailments like frequent stomach problems and skin irritation are considered 'very serious' health issues.

\section{Insert Fig. 9}

\section{Impact of proximity on perceived impact of landfill}

The factors affecting the perceived impact of the landfill are not only determined by the nature of the landfill but also by the variables such as resident's susceptibility toward the landfill, his or her geographic location concerning the landfill, and the perception of the specific problem concerning the landfill (Eyles et al. 1993; Okeke and Armour 2000). Therefore, the findings of LSI reported in table 3 appear to endorse the application of a geographical externality related to the public concerns around the Siliguri landfill. It is evident from the result that the landfill act as a spatial externality which includes severe consequences like releasing greenhouse and methane gases from the breakdown of organic wastes. There is also the possibility of consequences from the leaching of hazardous metals and chemicals into the surrounding, contaminating the water. Similarly, externalities include the impact of smells and burning issues on neighborhood amenities and the influence of air pollution. Thus, the impact of the landfill will contribute differently to the spatial externality, which impacts the perception of the respondents (Ahmad et al.2014).

However, the data analysis reveals that the public concern about the consequences of landfills develops in a cluster around the dumping site. The impact of proximity, measured in meters, on landfill impacts is shown in Table 2. Those who have no concerns with the landfill, with an LSI score of 6 , tend to live at the furthest distance from the dumping site. This tendency is especially evident in the LSI scores of respondents who live 600 meters away from the facility. Thus, only $8 \%$ of the respondents who live within $200 \mathrm{~m}$ report 'minor' to 'not at all problems', whereas $34 \%$ report severe problems living within this zone (Table 2). Therefore, as predicted, the data revealed, distance is inversely related to the impact of the landfill; as the distance increases, the level of perception about the impact of the dumping site decreases. People living within 200-600 meters of the site were the most concerned about the multiple impacts of landfills.

Insert Table 2

Insert Table 3 
Subsequently, it is clear that the Siliguri landfill is surrounded by the field of spatial externality, and thus to validate the perception of individual impacts and LSI, gamma coefficient (y-statistics) have been adopted (Table 3). The gamma coefficient, introduced by Goodman and Kruskal, is a symmetrical measure of connection between two ordinal variables that range from +1 to -1 (Norusis 1992). Values close to 1 indicate a strong link between the two variables, while values close to 0 suggest little or no association among the variables. The negative values towards 1 also indicate a positive association; as distance increases, perception also improves (Furuseth and Johnson 1988; Okeke and Armour 2000). In this research, the gamma coefficient statistics have been applied to assess the distance from the Siliguri dumpsite and individual perception of the landfill's consequences. However, the present findings reveal that the gamma coefficient (y) varies from 0.34 to 0.74 (Table 4). The findings reveal that all the factors of landfill impacts, including LSI, are statistically significant. Therefore, It is clear that the distance of the landfill influences all the factors. As expected, the factors like pungent odour (0.74), health-related issues (0.653), and the impact of flies, mosquitoes, and rodents (0.587) are highly associated with the distance of the landfill. Besides, factors like water contamination, breathing issues, and issues due to burning are also significantly associated with the distance of the respondents. Finally, the effect of distance on the overall assessment of landfill consequences was investigated in the same way. The finding reveals that the $y$-value of $L S I$ is 0.34 , which was also statistically significant but with less explanatory power than other landfill impact factors.

These findings show that the concept of distance decay is for public concern over the landfill, which is partly correct. As because some public issues related to the landfill are alleviated by increasing geographic distance, but not all. It means that standard measures for reducing landfill externalities, such as situating facilities away from densely populated areas or erecting barriers, may reduce in situ impacts but leave other traffic and environmental issues unaddressed. Despite this, the research supported the idea of a geographical externality field encircling the Siliguri landfill, indicating that geographic isolation was significant as a mitigating factor for managing the landfill's cumulative externalities. However, Figure 10 showing some glimpse of unscientific dumping in the Siliguri landfill

Insert Fig. 10

\section{Discussion And Conclusion}

Due to a shortage of space and rising human density, landfilling is a horrible waste management option in Siliguri city. The findings reveal that due to a lack of suitable land availability and personnel numbers, the Siliguri dump demonstrated a lack of effective management techniques. The absence of meaningful waste treatment facility consequences in the booming of mosquitoes, flies, and rodents, the existence of foul odours, contamination of surface water, choking of breath, and enhance the risk of health problems among the people in the area. According to the survey findings, all the respondents generally agreed that there should be a proper garbage disposal facility. However, owing to widespread public worries about possible health and environmental consequences, controversy arose while looking for acceptable dump

Page $12 / 30$ 
areas. Such a pattern of reaction among the respondents indicates the NIMBY - Not in my Backyard syndrome- one's objection to locating an unwanted and undesirable facility in their neighborhood. As expected, Residents who lived closer to the dumping yard were more worried about the facility's operating consequences, such as smell, the impact of insects, and so on. This finding adds to the growing body of evidence that geographical separation is a critical component in managing and reducing cumulative externalities created by facilities, as well as establishing the comfort zone around the landfill site.

However, the study depicts that residents within the $600 \mathrm{~m}$ are the most susceptible from the landfill site; therefore, it is plausible to assume that inhabitants in close proximity to the landfill site believe that distance is better in terms of physical and mental perceptions. The public's opposition to an MSW treatment plant is often linked to public health and environmental concerns. However, according to the findings, Odour nuisance and impacts of flies and mosquitoes were the most common worry, followed by groundwater contamination, breathing problem, health danger, and issues due to burning. Subsequently, residents' perceptions regarding most of the landfill effects were influenced by their geographical proximity.

The results show that Siliguri city's current SWM practices have the potential to become more organized and successful. In order to maintain environmental sustainability and equitable public health, the current waste management practices must be modified. Better primary waste disposal techniques are required to limit the amount of garbage that ends up in landfills. Through the media, such as newspaper advertising, pamphlets, and leaflets, it is critical to raise awareness among those involved in waste operations about the negative consequences of uncontrolled solid waste disposal. Awareness campaigns include enlightenment efforts, clean-up initiatives, and recycling drives must be adopted.

Subsequently, it is vital to prevent leachate from seeping and mixing with the adjacent water bodies in landfills, which may be accomplished by erecting a permanent protective barrier. Besides, protective vegetative covers around the landfill should be another effective approach to minimize the impact of odour. The landfills' organizational capability must be strengthened with enough technical and human assistance and adequate budget allocation for efficient SWM operations. Besides, it is necessary to relocate the existing landfill space because waste output increases due to excessive urbanization and population growth, which will exhaust the extra acreage in the next few years. The waste treatment and recycling process must be waste-reductive and waste-disposal-aware. Alternatives such as incineration and refuse-derived fuel (RDF) production should be investigated for their environmental and health implications.

Finally, the results of this study corroborated the findings of a spatial externality around LULUs (locally unwanted land use). Therefore, land-use planners and public authorities will benefit from a better knowledge of the properties and area extent of these fields. The findings can be beneficial for arranging the locational decision-making around these facilities, which can begin to define the spatial externality fields for different types of noxious land uses. Hence, this research may help urban decision-makers and the general public to realize the importance of enhancing health and sustainability in the city. 


\section{References}

Aatamila, M., Verkasalo, P. K., Korhonen, M. J., Viluksela, M. K., Pasanen, K., Tiittanen, P., \& Nevalainen, A. (2010). Odor annoyance near waste treatment centers: a population-based study in Finland. Journal of the Air \& Waste Management Association, 60(4), 412-418. https://doi.org/10.3155/1047-3289.60.4.412

Abul, S. (2010). Environmental and health impact of solid waste disposal at Mangwaneni dumpsite in Manzini: Swaziland. Journal of Sustainable development in Africa, 12(7), 64-78.

Addo, I. B., Adei, D., \& Acheampong, E. O. (2015). Solid waste management and its health implications on the dwellers of Kumasi metropolis, Ghana. Current Research Journal of Social Sciences, 7(3), 8193. http://dx.doi.org/10.19026/crjss.7.5225

Ahmad, S. Z., Ahamad, M. S. S., \& Yusoff, M. S. (2014). Spatial effect of new municipal solid waste landfill siting using different guidelines. Waste management \& research, 32(1), 24-33.

Ahmed, T., Hyder, M. Z., Liaqat, I., \& Scholz, M. (2019). Climatic conditions: Conventional and nanotechnology-based methods for the control of mosquito vectors causing human health issues. International journal of environmental research and public health, 16(17), 3165. https://dx.doi.org/10.3390\%2Fijerph16173165

Akinbile, C. O., \& Yusoff, M. (2011). Assessment of groundwater quality near a municipal landfill in Akure, Nigeria. In 2011 2nd International Conference on Environmental Science and Technology. Singapore: IACSIT Press.

Alam, P., \& Ahmade, K. (2013). Impact of solid waste on health and the environment. International Journal of Sustainable Development and Green Economics (IJSDGE), 2(1), 165-168.

Asnani, P. U., \& Zurbrugg, C. (2007). Improving municipal solid waste management in India: A sourcebook for policymakers and practitioners. World Bank Publications.

Babs-Shomoye, F., \& Kabir, R. (2016). Health effects of solid waste disposal at a dumpsite on the surrounding human settlements. Journal of Public Health in Developing Countries, 2(3), 268-275.

Balram, S., \& Dragićević, S. (2005). Attitudes toward urban green spaces: integrating questionnaire survey and collaborative GIS techniques to improve attitude measurements. Landscape and urban planning, 71(2-4), 147-162.

Blumberg, L., \& Gottlieb, R. (1989). War on waste: can America win its battle with garbage?. Island Press.

Boadi, K. O., \& Kuitunen, M. (2005). Environmental and health impacts of household solid waste handling and disposal practices in third world cities: the case of the Accra Metropolitan Area, Ghana. Journal of environmental health, 68(4). 
Bobeck, M. (2010). Organic Household Waste in Developing Countries: An overview of environmental and health consequences, and appropriate decentralised technologies and strategies for sustainable management.

Brender, J. D., Maantay, J. A., \& Chakraborty, J. (2011). Residential proximity to environmental hazards and adverse health outcomes. American journal of public health, 101(S1), S37-

S52. https://dx.doi.org/10.2105\%2FAJPH.2011.300183

Bridges, O., Bridges, J. W., \& Potter, J. F. (2000). A generic comparison of the airborne risks to human health from landfill and incinerator disposal of municipal solid waste. Environmentalist, 20(4), 325-334.

CDP report Siliguri, 2015. City Development Plan for Siliguri 2041. Capac- ity Building for Urban Development Project, Ministry of Urban Development. Accessed http://siligurismc.in/userfiles/file/siliguriCDP-final-report-29April15.pdf.

Che, Y., Yang, K., Jin, Y., Zhang, W., Shang, Z., \& Tai, J. (2013). Residents' concerns and attitudes toward a municipal solid waste landfill: integrating a questionnaire survey and GIS techniques. Environmental monitoring and assessment, 185(12), 10001-10013. https://doi.org/10.1007/s10661-013-3308-y

De, S., \& Debnath, B. (2016). Prevalence of health hazards associated with solid waste disposal-A case study of kolkata, India. Procedia Environmental Sciences, 35, 201-

208. https://doi.org/10.1016/j.proenv.2016.07.081

Dhillon, M.S. \& Challet, G.L. (1985) The evaluation of three sampling techniques for the determination of fly (Diptera) densities at four sanitary landfills in southern California. Bulletin of the Society of Vector Ecology, 10, 36-40.

Edokpayi, J. N., Durowoju, O. S., \& Odiyo, J. O. (2018). Assessment of heavy metals in landfill leachate: a case study of Thohoyandou landfill, Limpopo Province, South Africa. Heavy Met.

Ejaz, N., Akhtar, N., Hashmi, H., \& Naeem, U. A. (2010). Environmental impacts of improper solid waste management in developing countries: A case study of Rawalpindi city. The sustainable world, 142, 379387. https://doi.org/10.1016/j.landurbplan.2004.02.007

Escobar-Arnanz, J., Mekni, S., Blanco, G., Eljarrat, E., Barceló, D., \& Ramos, L. (2018). Characterization of organic aromatic compounds in soils affected by an uncontrolled tire landfill fire through the use of comprehensive two-dimensional gas chromatography-time-of-flight mass spectrometry. Journal of Chromatography A, 1536, 163-175. https://doi.org/10.1016/j.chroma.2017.10.044

Etea, T., Girma, E., \& Mamo, K. (2021). Risk Perceptions and Experiences of Residents Living Nearby Municipal Solid Waste Open Dumpsite in Ginchi Town, Ethiopia: A Qualitative Study. Risk Management and Healthcare Policy, 14, 2035. https://doi.org/10.2147/RMHP.S309295 
Eyles, J., Taylor, S. M., Johnson, N., \& Baxter, J. (1993). Worrying about waste: living close to solid waste disposal facilities in southern Ontario. Social Science \& Medicine, 37(6), 805-

812. https://doi.org/10.1016/0277-9536(93)90374-D

Firdaus, G., \& Ahmad, A. (2010). Management of urban solid waste pollution in developing countries.

Furuseth, O. J., \& Johnson, M. S. (1988). Neighbourhood attitudes towards a sanitary landfill: A North Carolina study. Applied Geography, 8(2), 135-145.

Ganesan, P. (2017). Landfill sites, solid waste management and people's resistance: a study of two municipal corporations in Kerala. International Journal of Environmental Studies, 74(6), 958978. https://doi.org/10.1080/00207233.2017.1374076

Gouveia, N., \& Prado, R. R. D. (2010). Health risks in areas close to urban solid waste landfill sites. Revista de saude publica, 44, 859-866. https://doi.org/10.1590/S0034-89102010005000029

He, Z., Li, G., Chen, J., Huang, Y., An, T., \& Zhang, C. (2015). Pollution characteristics and health risk assessment of volatile organic compounds emitted from different plastic solid waste recycling workshops. Environment international, 77, 85-94. https://doi.org/10.1016/j.envint.2015.01.004

Heldal, K. K., Halstensen, A. S., Thorn, J., Eduard, W., \& Halstensen, T. S. (2003). Airway inflammation in waste handlers exposed to bioaerosols assessed by induced sputum. European Respiratory Journal, 21(4), 641-645.

Henry, R. K., Yongsheng, Z., \& Jun, D. (2006). Municipal solid waste management challenges in developing countries-Kenyan case study. Waste management, 26(1), 92-

100. https://doi.org/10.1016/j.wasman.2005.03.007

Higgs, G., \& Langford, M. (2009). GIScience, environmental justice, \& estimating populations at risk: The case of landfills in Wales. Applied Geography, 29(1), 63-

76. https://doi.org/10.1016/j.apgeog.2008.07.006

Howard, J. (2001). Nuisance flies around a landfill: patterns of abundance and distribution. Waste management \& research, 19(4), 308-313. https://doi.org/10.1177\%2F0734242X0101900407

ICCDI Africa. (2020). Leachate: An Avoidable Threat To Human Health And The Environment. Accesed: https://medium.com/climatewed/leachate-an-avoidable-threat-to-human-health-and-theenvironment-by-amah-onyedikachi-6593f1fbf3d4

Joshi, R., \& Ahmed, S. (2016). Status and challenges of municipal solid waste management in India: A review. Cogent Environmental Science, 2(1), 1139434. https://doi.org/10.1080/23311843.2016.1139434

Kret, J., Dame, L. D., Tutlam, N., DeClue, R. W., Schmidt, S., Donaldson, K., ... \& Khan, F. (2018). A respiratory health survey of a subsurface smoldering landfill. Environmental research, 166, 427- 
436. https://doi.org/10.1016/j.envres.2018.05.025

Kumari, K., Kumar, S., Rajagopal, V., Khare, A., \& Kumar, R. (2019). Emission from open burning of municipal solid waste in India. Environmental technology, 40(17), 2201-

2214. https://doi.org/10.1080/09593330.2017.1351489

Lim, S. L., Lee, L. H., \& Wu, T. Y. (2016). Sustainability of using composting and vermicomposting technologies for organic solid waste biotransformation: recent overview, greenhouse gases emissions and economic analysis. Journal of Cleaner Production, 111, 262-

278. https://doi.org/10.1016/j.jclepro.2015.08.083

Lole, M. J. (2005). Nuisance flies and landfill activities: an investigation at a West Midlands landfill site. Waste management \& research, 23(5), 420-428. https://doi.org/10.1177\%2F0734242X05057694

Maqbool, F., Bhatti, Z. A., Malik, A. H., Pervez, A., \& Mahmood, Q. (2011). Effect of landfill leachate on the stream water quality.

Marshall, R. E., \& Farahbakhsh, K. (2013). Systems approaches to integrated solid waste management in developing countries. Waste management, 33(4), 988-

1003. https://doi.org/10.1016/j.wasman.2012.12.023

Mataloni, F., Badaloni, C., Golini, M. N., Bolignano, A., Bucci, S., Sozzi, R., ... \& Ancona, C. (2016). Morbidity and mortality of people who live close to municipal waste landfills: a multisite cohort study. International journal of epidemiology, 45(3), 806-815. https://doi.org/10.1093/ije/dyw052

Moser, A., \& Korstjens, I. (2018). Series: Practical guidance to qualitative research. Part 3: Sampling, data collection and analysis, European Journal of General Practice, 4(1), 9-

18, https://doi.org/10.1080/13814788.2017.1375091

Nadal, M., Rovira, J., Díaz-Ferrero, J., Schuhmacher, M., \& Domingo, J. L. (2016). Human exposure to environmental pollutants after a tire landfill fire in Spain: Health risks. Environment international, 97, 3744. https://doi.org/10.1016/j.envint.2016.10.016

Njoku, P. O., Edokpayi, J. N., \& Odiyo, J. O. (2019). Health and environmental risks of residents living close to a landfill: A case study of Thohoyandou Landfill, Limpopo Province, South Africa. International journal of environmental research and public health, 16(12), 2125. https://doi.org/10.3390/ijerph16122125

Norusis, M. J. (1992). SPSS inc. SPSS for Windows. IL: SPSS Inc.

Ojha, K. (2011). Status of MSW management system in northern India-an overview. Environment, development and sustainability, 13(1), 203-215. https://doi.org/10.1007/s10668-010-9256-6

Okeke, C. U., \& Armour, A. (2000). Post-landfill siting perceptions of nearby residents: a case study of Halton landfill. Applied Geography, 20(2), 137-154. https://doi.org/10.1016/S0143-6228(00)00003-5 
Ololade, O. O., Mavimbela, S., Oke, S. A., \& Makhadi, R. (2019). Impact of leachate from northern landfill site in Bloemfontein on water and soil quality: Implications for water and food security. Sustainability, 11(15), 4238. https://doi.org/10.3390/su11154238

Palmiotto, M., Fattore, E., Paiano, V., Celeste, G., Colombo, A., \& Davoli, E. (2014). Influence of a municipal solid waste landfill in the surrounding environment: Toxicological risk and odor nuisance effects. Environment international, 68, 16-24. https://doi.org/10.1016/j.envint.2014.03.004

Porta, D., Milani, S., Lazzarino, A. I., Perucci, C. A., \& Forastiere, F. (2009). Systematic review of epidemiological studies on health effects associated with management of solid waste. Environmental health, 8(1), 1-14.

Purcell, M., \& Magette, W. L. (2010). Attitudes and behaviour towards waste management in the Dublin, Ireland region. Waste management, 30(10), 1997-2006.

Rahardyan, B., Matsuto, T., Kakuta, Y., \& Tanaka, N. (2004). Resident's concerns and attitudes towards Solid Waste Management facilities. Waste management, 24(5), 437-451.

Reference

Reinhart, D. R. (1993). A review of recent studies on the sources of hazardous compounds emitted from solid waste landfills: a US experience. Waste Management \& Research, 11(3), 257-268.

Roberts, R. J., \& Chen, M. (2006). Waste incineration-how big is the health risk? A quantitative method to allow comparison with other health risks. Journal of Public Health, 28(3), 261-266.

Rovira, J., Domínguez-Morueco, N., Nadal, M., Schuhmacher, M., \& Domingo, J. L. (2018). Temporal trend in the levels of polycyclic aromatic hydrocarbons emitted in a big tire landfill fire in Spain: Risk assessment for human health. Journal of Environmental Science and Health, Part A, 53(3), 222229. https://doi.org/10.1080/10934529.2017.1387023

Roy, S., \& Mandal, G. (2019). Municipal Solid Waste: A Major Footprint in Urban Environment of Siliguri. RESEARCH REVIEW International Journal of Multidisciplinary, 4(5), 406-416.

Roy, S., \& Singha, N. (2020). Analysis of Ambient Air Quality Based On Exceedance Factor and Air Quality Index for Siliguri City, West Bengal. Current World Environment, 15(2), 235. http://dx.doi.org/10.12944/CWE.15.2.11

Roy, S., Bose, A., Singha, N., Basak, D., \& Chowdhury, I. R. (2021). Urban waterlogging risk as an undervalued environmental challenge: An Integrated MCDA-GIS based modeling approach. Environmental Challenges, 4, 100194. https://doi.org/10.1016/j.envc.2021.100194

Rushton, L. (2003). Health hazards and waste management. British medical bulletin, 68(1), 183-197. 
Sankoh, F. P., Yan, X., \& Tran, Q. (2013). Environmental and health impact of solid waste disposal in developing cities: a case study of granville brook dumpsite, Freetown, Sierra Leone. Journal of Environmental Protection, 2013.

Sankoh, F. P., Yan, X., \& Tran, Q. (2013). Environmental and health impact of solid waste disposal in developing cities: a case study of granville brook dumpsite, Freetown, Sierra Leone. Journal of Environmental Protection, 2013.

Semrau, J. D. (2011). Current knowledge of microbial community structures in landfills and its cover soils. Applied microbiology and biotechnology, 89(4), 961-969.

Sharholy, M., Ahmad, K., Mahmood, G., \& Trivedi, R. C. (2008). Municipal solid waste management in Indian cities-A review. Waste management, 28(2), 459-467.

Siliguri Times. (2021). Fire breaks out at Siliguri's dumping ground once again. https://siliguritimes.com/fire-breaks-out-at-siliguris-dumping-ground-once-again/

Silverman, R. A., \& Ito, K. (2010). Age-related association of fine particles and ozone with severe acute asthma in New York City. Journal of Allergy and Clinical Immunology, 125(2), 367-

373. https://doi.org/10.1016/j.jaci.2009.10.061

Singh, S. K., Chokhandre, P., Salve, P. S., \& Rajak, R. (2021). Open dumping site and health risks to proximate communities in Mumbai, India: A cross-sectional case-comparison study. Clinical Epidemiology and Global Health, 9, 34-40. https://doi.org/10.1016/j.cegh.2020.06.008

Slovic, P. E. (2000). The perception of risk. Earthscan publications.

Srangsriwong, A., Olapiriyakul, S., \& Yenradee, P. (2019). Factors influencing public perception and impact distance of a municipal solid waste dumpsite in Thailand. Asia-Pacific Journal of Science and Technology, 24(1).

Srivastava, V., Ismail, S. A., Singh, P., \& Singh, R. P. (2015). Urban solid waste management in the developing world with emphasis on India: challenges and opportunities. Reviews in Environmental Science and Bio/Technology, 14(2), 317-337. https://doi.org/10.1007/s11157-014-9352-4

The Conversion. (2018). Why your summer might be full of mosquitoes, according to a scientist. Accessed: https://theconversation.com/why-your-summer-might-be-full-of-mosquitoes-according-to-ascientist-98369

Toro, R., \& Morales, L. (2018). Landfill fire and airborne aerosols in a large city: lessons learned and future needs. Air Quality, Atmosphere \& Health, 11(1), 111-121. https://doi.org/10.1007/s11869-017-0522-8

Tyagi, V., Fantaw, S., \& Sharma, H. R. (2014). Municipal solid waste management in Debre Berhan City of Ethiopia. J Environ Earth Sci, 4(5), 98-103. 
Urme, S. A., Radia, M. A., Alam, R., Chowdhury, M. U., Hasan, S., Ahmed, S., ... \& Quayyum, Z. (2021). Dhaka landfill waste practices: addressing urban pollution and health hazards. Buildings \& cities, 2(1), 700. http://doi.org/10.5334/bc.108

Vaverková, M. D. (2019). Landfill impacts on the environment. Geosciences, 9(10), 431. https://doi.org/10.3390/geosciences 9100431

Vimercati, L., Baldassarre, A., Gatti, M. F., De Maria, L., Caputi, A., Dirodi, A. A., ... \& Bellino, R. M. (2016). Respiratory health in waste collection and disposal workers. International journal of environmental research and public health, 13(7), 631. https://doi.org/10.3390/ijerph13070631

Vrijheid, M. (2000). Health effects of residence near hazardous waste landfill sites: a review of epidemiologic literature. Environmental health perspectives, 108(suppl 1), 101-112.

Weldeyohanis, Y. H., Aneseyee, A. B., \& Sodango, T. H. (2020). Evaluation of current solid waste disposal site based on socio-economic and geospatial data: a case study of Wolkite town, Ethiopia. GeoJournal, 117. https://doi.org/10.1007/s10708-020-10268-3

Zanobetti, A., Schwartz, J., \& Gold, D. (2000). Are there sensitive subgroups for the effects of airborne particles?. Environmental Health Perspectives, 108(9), 841-845.

Zohoori, M., \& Ghani, A. (2017). Municipal solid waste management challenges and problems for cities in low-income and developing countries. Int. J. Sci. Eng. Appl, 6(2), 39-48.

\section{Declarations}

\section{Credit authorship}

S.R. - Writing - Original Draft, Review \& Editing, Conceptualization, Methodology, Software, Validation A.B. \& D.B. Formal analysis, Review \& Editing and Methodology, I.R.C. - Review \& Editing, Supervision, Validation

This research study is carried out in compliance with transparency, field knowledge, moral values and hard work.

\section{Ethics approval}

Not applicable

\section{Declaration of Competing Interest}

The authors declare that they have no known competing financial interests or personal relationships that could have appeared to influence the work reported in this paper. 
Consent to participate:

All respondents consent are taken and they gave their will to voluntarily take part in the study.

Consent to publish:

All the authors have read the manuscript carefully before submitting and give consent to submit.

Funding: None.

Availability of data and materials: Data are provided upon reasonable request.

\section{Acknowledgments}

Firstly, the authors would like to express their sincere gratitude to the Department of Geography \& Applied Geography, University of North Bengal for providing opportunity in conducting the research work. Besides, the authors would like to express their sincere gratitude to the respondents for their favourable response during the field survey without which it is not possible to find such novel result.

\section{Tables}

Table 1 Perceived impact by the respondent due to open landfill

\begin{tabular}{lccccc}
\hline Landfill impacts & $\begin{array}{c}\text { Very serious } \\
\text { problem }\end{array}$ & $\begin{array}{c}\text { Serious } \\
\text { problem }\end{array}$ & $\begin{array}{c}\text { Moderate } \\
\text { problem }\end{array}$ & $\begin{array}{c}\text { Minor } \\
\text { problem }\end{array}$ & $\begin{array}{c}\text { Not at all a } \\
\text { problem }\end{array}$ \\
\hline Pungent odour & 28.6 & 25.0 & 19.5 & 16.1 & 10.7 \\
Vater contamination & 26.3 & 22.1 & 27.3 & 12.5 & 11.7 \\
Breathing problems & 24.0 & 24.2 & 23.2 & 15.9 & 12.8 \\
ssues due to burning & 25.5 & 5.7 & 5.2 & 29.9 & 33.6 \\
$\quad$ Impact of flies, & & & & & \\
losquitoes \& rodents & 36.2 & 39.1 & 19.8 & 2.6 & 2.3 \\
Iealth related issues & 24.2 & 17.4 & 13.8 & 20.6 & 24.0 \\
\hline
\end{tabular}

Table 2 Impact of proximity over the composite landfill evaluation score (\%)

\begin{tabular}{ccccccc}
\hline & & \multicolumn{5}{c}{ Respondent distances from Siliguri landfill (in m) } \\
\cline { 3 - 7 } Scale & $\mathrm{N}$ & $<200$ & $200-400$ & $400-600$ & $600-800$ & $800-1000$ \\
\hline $6-12^{\text {a }}$ & 107 & 8 & 12 & 16 & 27 & 36 \\
$13-20^{\mathrm{a}}$ & 112 & 26 & 21 & 23 & 23 & 6 \\
\hline $21-30$ & 165 & 34 & 37 & 16 & 10 & 3 \\
\hline a The total of the row does not equal to $100 \%$ due to rounding \\
\hline
\end{tabular}

Table 3 Association between proximity to landfill and its impact over the respondents 


\begin{tabular}{lccc}
\hline Landfill impact & GK (y) & P value & Result \\
\hline Pungent odour & -0.740 & $0.000^{* *}$ & sig. \\
Water contamination & -0.432 & $0.004^{* *}$ & sig. \\
\hline Breathing problems & -0.460 & $0.001^{* *}$ & sig. \\
\hline Issues due to burning & -0.391 & $0.008^{* *}$ & sig. \\
\hline Impact of flies, mosquitoes \& rodents & -0.587 & $0.000^{* *}$ & sig. \\
\hline Health related issues & -0.653 & $0.000^{* *}$ & sig. \\
\hline LSI & -0.34 & $0.03^{*}$ & sig \\
\hline GK- Goodman-Kruskal Gamma coefficient (y) & & \\
** Significant at the 1\% level, & & & \\
$*$ significant at the 5\% level & & & \\
\hline
\end{tabular}

\section{Figures}

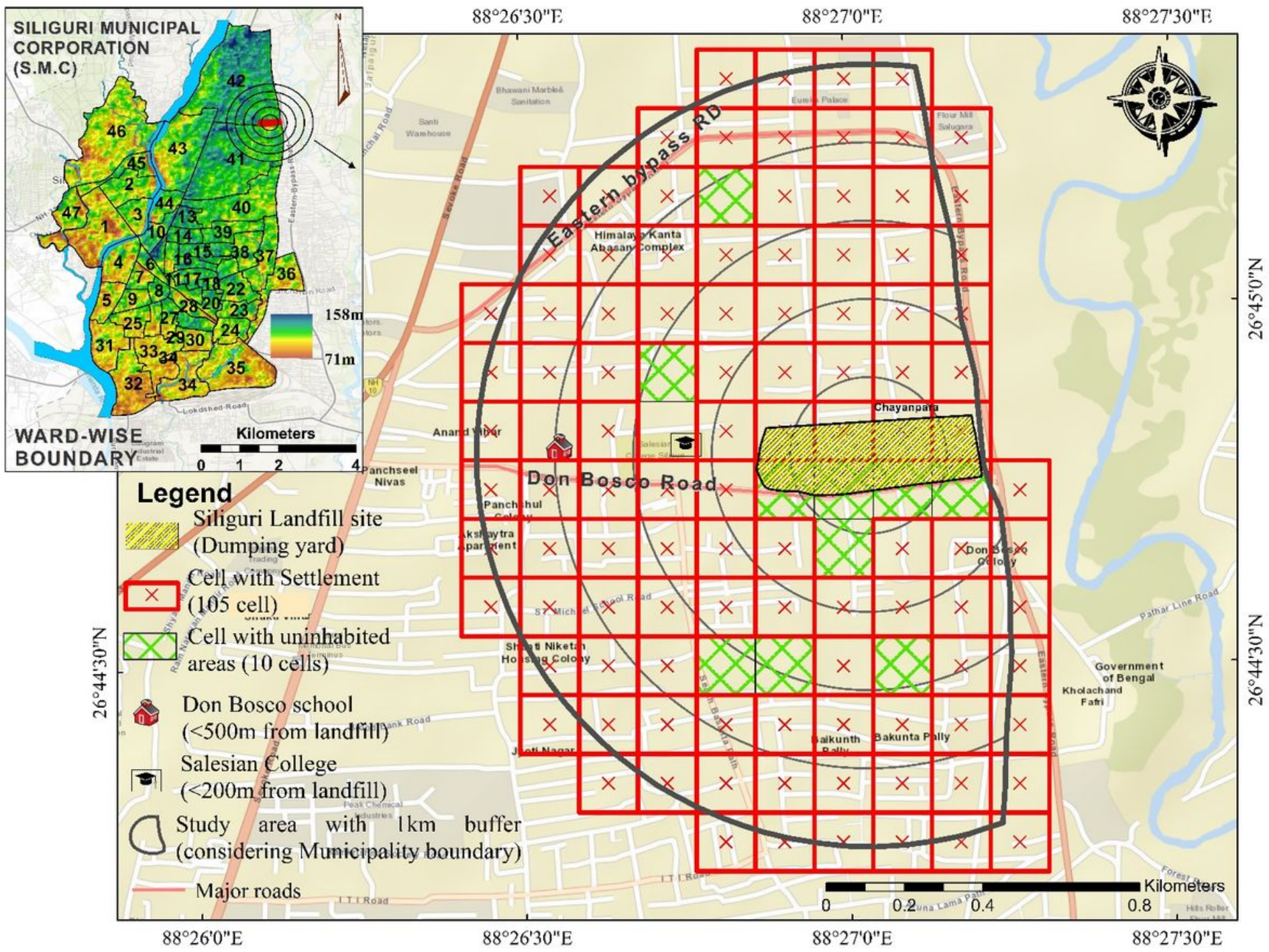

Figure 1 
Location map of the study area $(1000 \mathrm{~m}$ buffer at an interval of $200 \mathrm{~m}$ around the Siliguri landfill concerning municipal boundary). The map also showing DEM of Siliguri municipal corporation, rivers and wad-wise boundary. Total 115 grids $(150 \mathrm{~m})$ was identified around landfill site among which 10 grids are uninhabited.

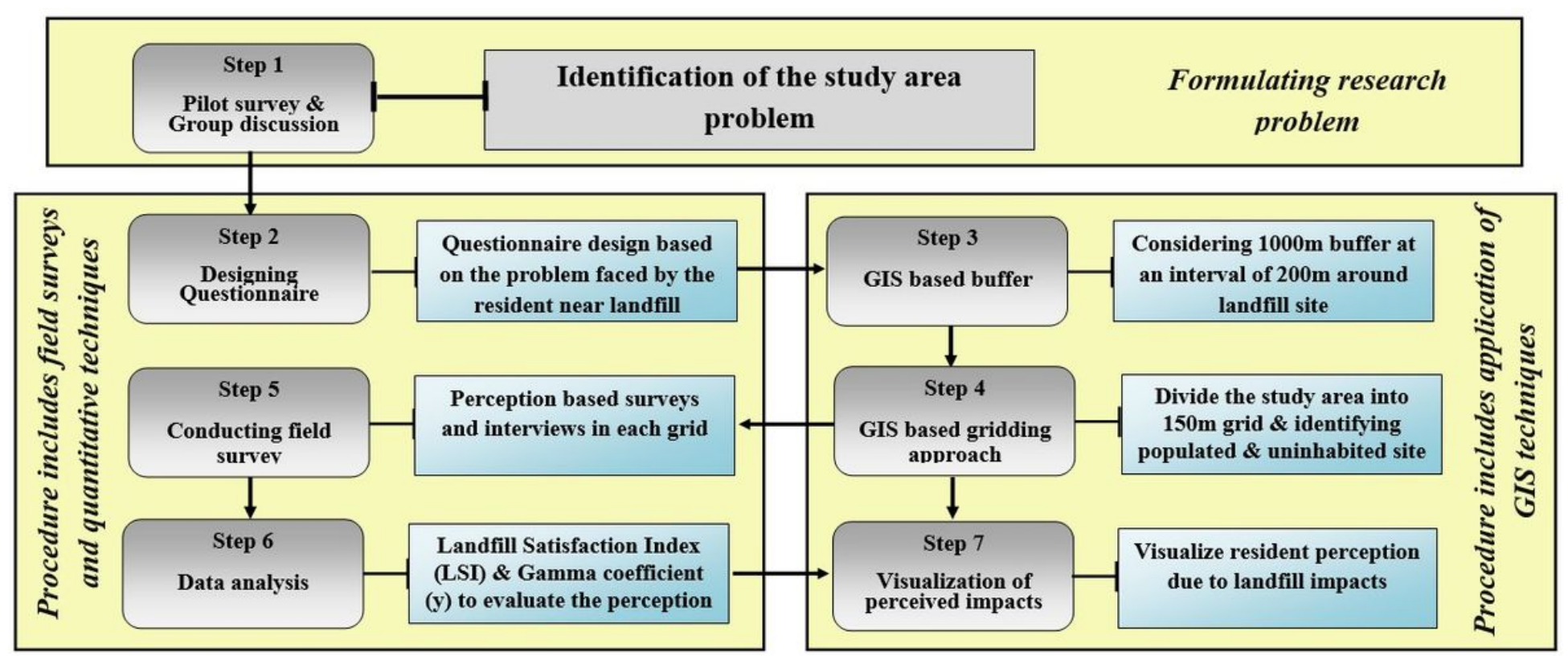

Figure 2

Methodological flowchart of the present study integrated using questionnaire and GIS based approach
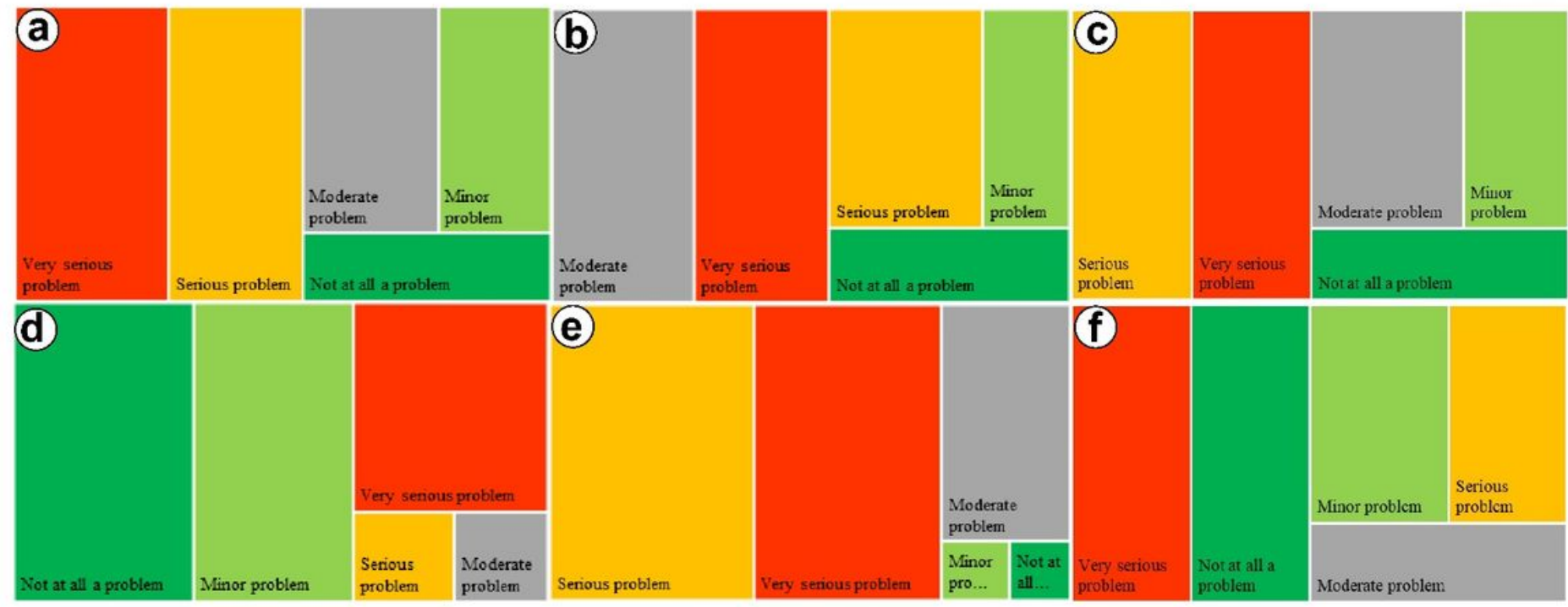

Figure 3 
Tree map showing perception of the respondent concerning landfill impacts (a) Pungent odour, (b) Perceived water contamination (c) Breathing issues (d) Issues due to burning, (e) Impact due to flies, mosquitoes \& rodents, (f) Health related issues

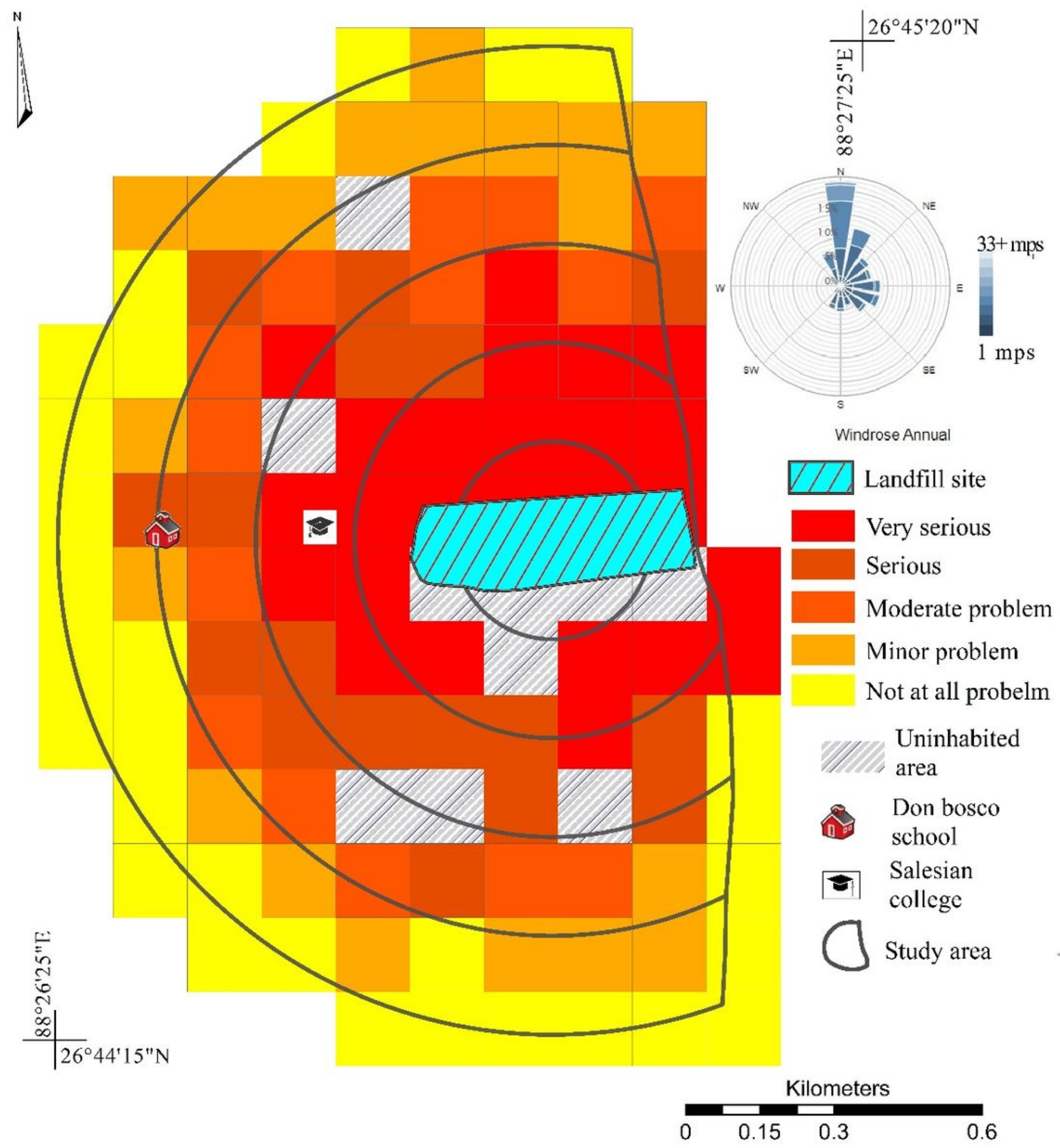

Figure 4 
Perceived issue due to pungent odour. The figure also showing annual wind direction and wind speed.

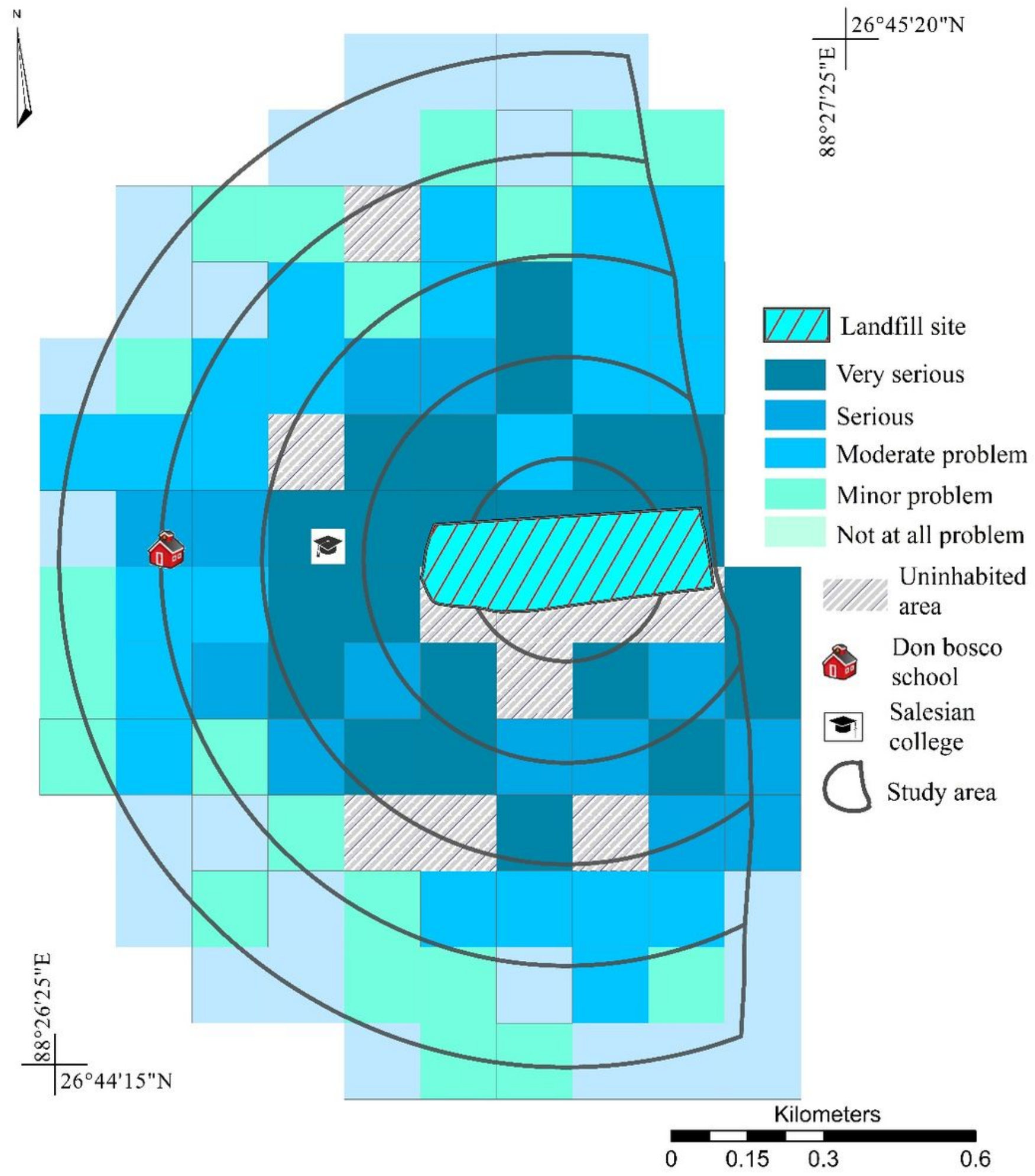

Figure 5

Perceived issue due to water contamination. 


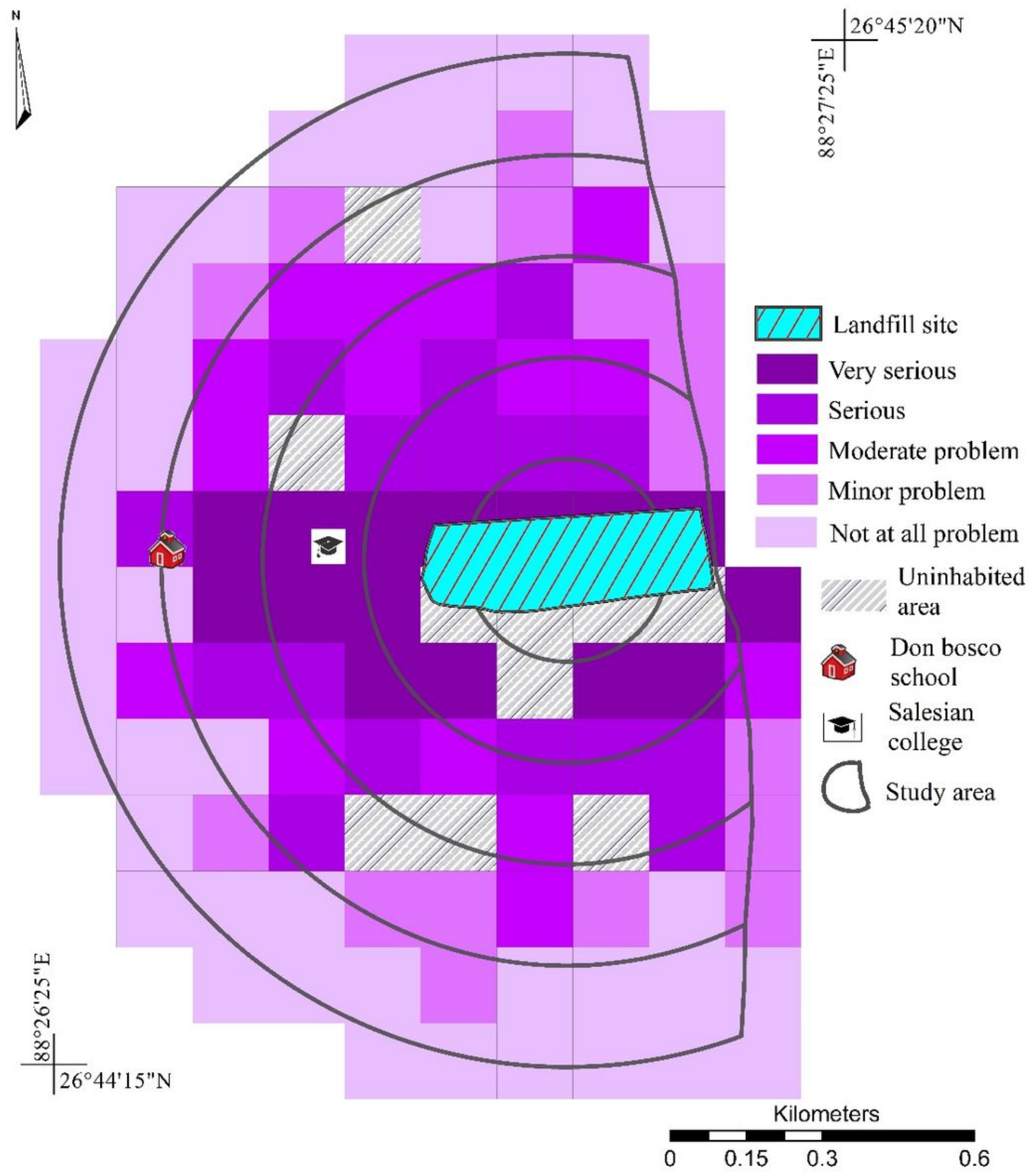

Figure 6

Perceived breathing issues. 


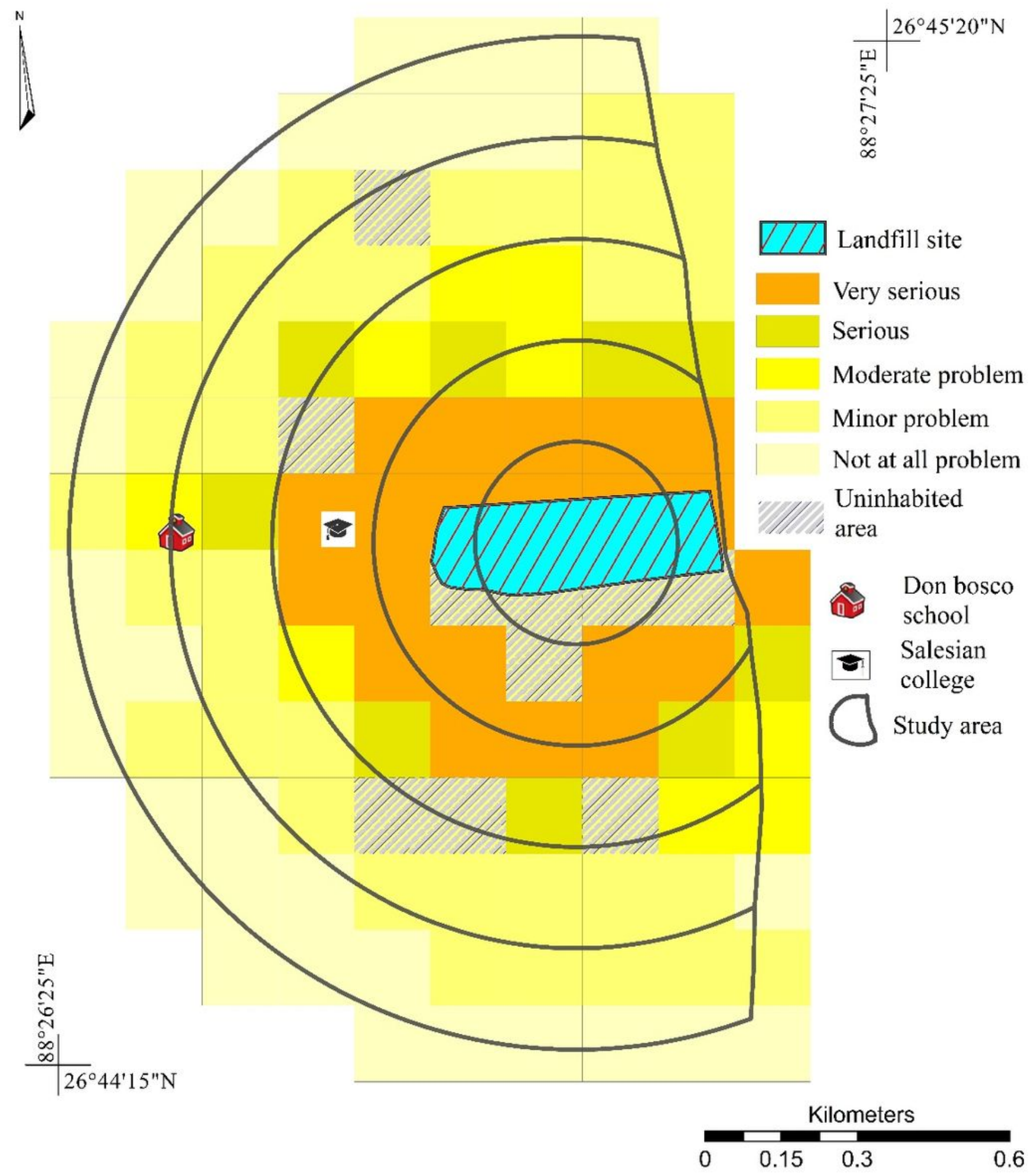

Figure 7

Perceived issues due to the frequent burning near landfill. 


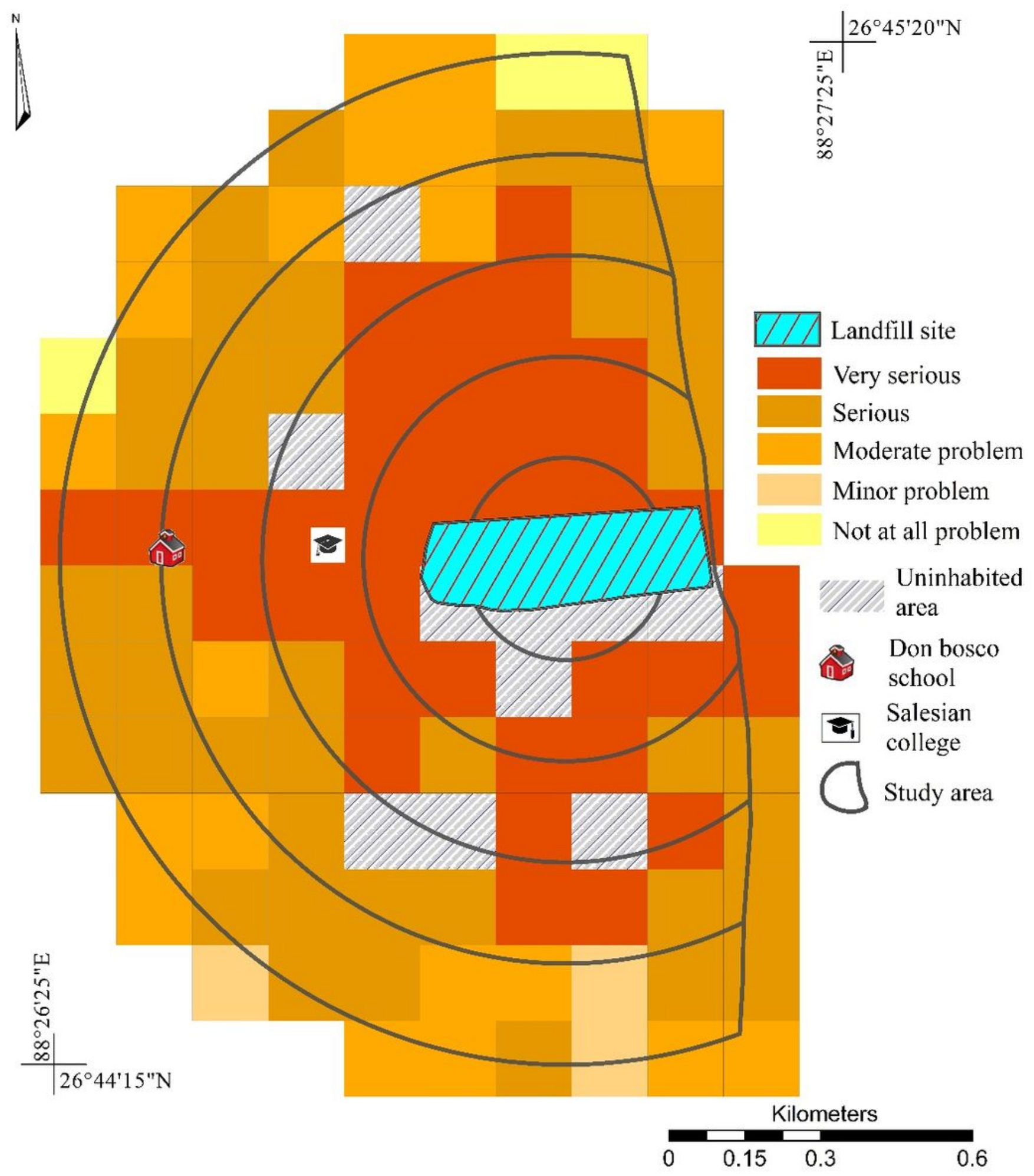

Figure 8

Perceived issues due to the impact of flies, mosquitoes and rodents. 


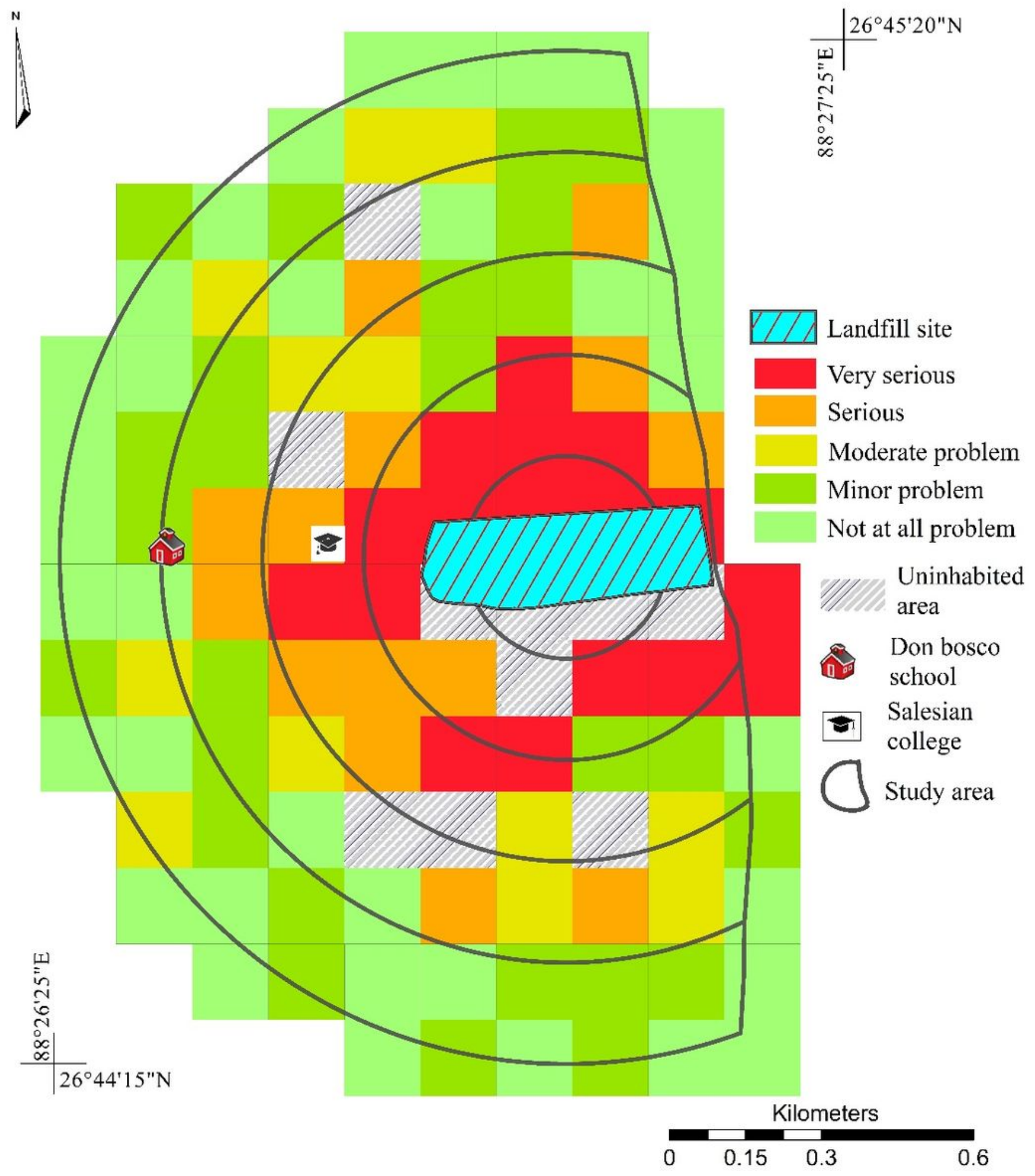

Figure 9

Perceived health-related issues near landfill. 


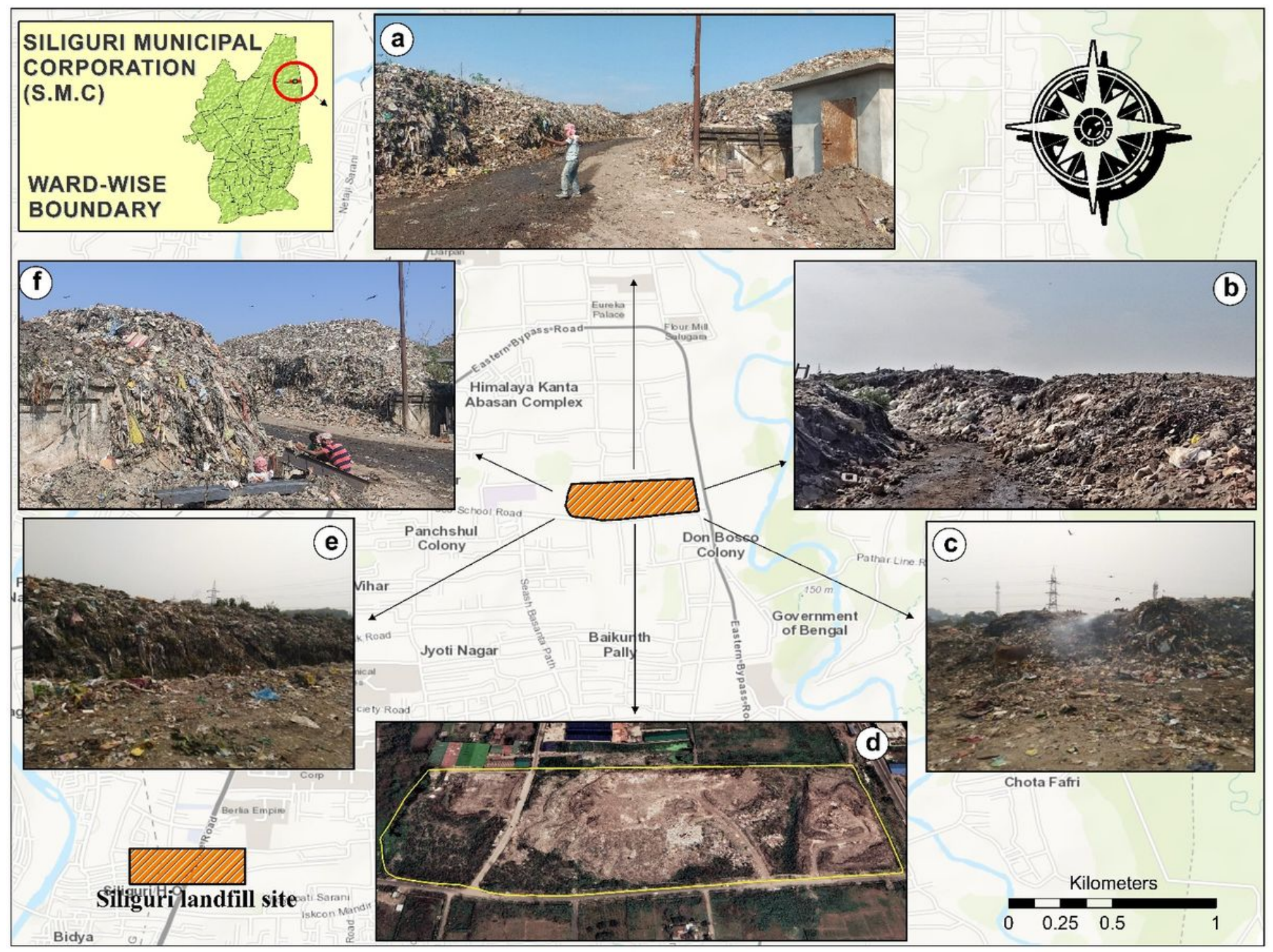

Figure 10

Glimpse of Siliguri open landfill site ( $a, b, e, f)$ Mountain of garbage's dumped in an unscientific way, (e) Illegal burning captured near landfill site, (f) Aerial view Siliguri landfill captured using Google earth images.

\section{Supplementary Files}

This is a list of supplementary files associated with this preprint. Click to download.

- Supplementary.docx 